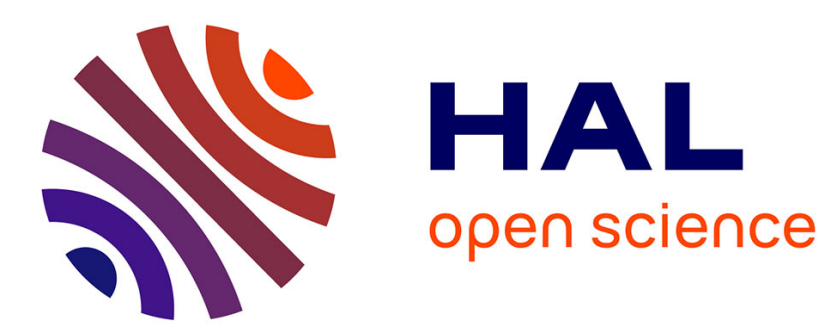

\title{
Relative toxicity for indoor semi volatile organic compounds based on neuronal death
}

Kevin Fournier, Emmanuel Baumont, Philippe Glorennec, Nathalie Bonvallot

\section{To cite this version:}

Kevin Fournier, Emmanuel Baumont, Philippe Glorennec, Nathalie Bonvallot. Relative toxicity for indoor semi volatile organic compounds based on neuronal death. Toxicology Letters, 2017, 279, pp.33-42. 10.1016/j.toxlet.2017.07.875 . hal-01579605

\section{HAL Id: hal-01579605 \\ https://hal-univ-rennes1.archives-ouvertes.fr/hal-01579605}

Submitted on 31 Aug 2017

HAL is a multi-disciplinary open access archive for the deposit and dissemination of scientific research documents, whether they are published or not. The documents may come from teaching and research institutions in France or abroad, or from public or private research centers.
L'archive ouverte pluridisciplinaire HAL, est destinée au dépôt et à la diffusion de documents scientifiques de niveau recherche, publiés ou non, émanant des établissements d'enseignement et de recherche français ou étrangers, des laboratoires publics ou privés. 


\title{
Relative toxicity for indoor semi volatile organic compounds based on neuronal death
}

\author{
Kevin Fournier ${ }^{\mathrm{a}, \mathrm{b}}$, Emmanuel Baumont ${ }^{\mathrm{a}, \mathrm{b}}$, Philippe Glorennec $^{\mathrm{a}, \mathrm{b}}$, Nathalie Bonvallot ${ }^{\mathrm{a}, \mathrm{b}}$
}

a EHESP School of Public Health, Rennes, Sorbonne Paris Cité, Avenue du Professeur Léon Bernard, 35043

Rennes Cedex, France

b INSERM UMR1085 IRSET (Research Institute in Environmental and Occupational Health), Rennes, France

Kevin Fournier: kevin.fournier01@gmail.com

Emmanuel Baumont: emmanuel.baumont@cstb.fr

Philippe Glorennec: philippe.glorennec@ehesp.fr

Nathalie Bonvallot (corresponding author): nathalie.bonvallot@ehesp.fr

Avenue du Pr. Léon Bernard, 35000 RENNES, France

Highlights

- Many indoor SVOCs are suspected to be neurotoxic, raising the question of cumulative risk assessment

- Benchmark concentrations (BMC) have been derived for 13 / 28 neurotoxic indoor SVOCs

- Experimental designs had a significant influence on BMC calculation

- More standardized protocols in terms of cell lines, species and exposure duration should be developed with a view to cumulative risk assessment

\begin{abstract}
Background: Semi Volatile Organic Compounds (SVOCs) are contaminants commonly found in dwellings as a result of their use as plasticizers, flame retardants, or pesticides in building materials and consumer products. Many SVOCs are suspected of being neurotoxic, based on mammal experimentation (impairment of locomotor activity, spatial learning/memory or behavioral changes), raising the question of cumulative risk assessment.
\end{abstract}


The aim of this work is to estimate the relative toxicity of such SVOCs, based on neuronal death.

Method: SVOCs fulfilling the following conditions were included: detection frequency $>10 \%$ in dwellings, availability of data on effects or mechanism of action for neurotoxicity, and availability of dose-response relationships based on cell viability assays as a proxy of neuronal death. Benchmark concentration values (BMC) were estimated using a Hill model, and compared to assess relative toxicity.

Results: Of the 58 SVOCs selected, 28 were suspected of being neurotoxic in mammals, and 21 have been documented as inducing a decrease in cell viability in vitro. 13 have at least one dose-response relationship that can be used to derive a BMC based on a $10 \%$ fall in neuronal viability. Based on this in vitro endpoint, PCB-153 appeared to be the most toxic compound, having the lowest $\mathrm{BMC}_{10}(0.072 \mu \mathrm{M})$ and diazinon the least toxic compound, having the highest $\mathrm{BMC}_{10}(94.35 \mu \mathrm{M})$. We showed that experimental designs (in particular choice of cell lines) had a significant influence on BMC calculation.

Conclusion: For the first time, the relative in vitro toxicity of 13 indoor contaminants belonging to different chemical families has been assessed on the basis of neuronal cell viability. Lack of comparable toxicity datasets limits the number of SVOCs that can be included. More standardized protocols in terms of cell lines, species and exposure duration should be developed with a view to cumulative risk assessment.

\section{Abbreviations}

AIF

Apoptosis-inducing factor

$\mathrm{B}(\mathrm{a}) \mathrm{P}$

Benzo(a)pyrene

Bax

$\mathrm{Bcl} 2$ associated $\mathrm{X}$ protein

BBP

Benzylbutylphtalate 
BDE-X

BMC

BMCL

BMCU

BMR

BPA

$\mathrm{Ca} 2+$

CCK-8

Cyto c

DBP

DDE or 4,4'-DDE

DDT or $4,4^{\prime}$-DDT

DEHP

DEP

DiBP

DiNP

DMEP

DMP

EFSA

EPA

GD

HI

MTS
Bromodiphenylether - congener X

Benchmark concentration

Benchmark concentration lower bound

Benchmark concentration upper bound

Benchmark response

Bisphenol A

Calcium

Cell counting kit-8

Cytochrome c

Di-n-butylphtalate

Di-chlorodiphenyldichloroethylene

Di-chlorodiphenyltrichloroethane

Di-ethylhexylphtalate

Di-ethylphtalate

Di-isobutylphtalate

Di-isononylphtalate

Di(2-methoxyethyl)phthalate

Di-methylphtalate

European Food Safety Authority

Environmental Protection Agency

Gestational day

Hazard index

3-(4,5-dimethylthiazol-2-yl)-5-(3-carboxymethoxyphenyl)-2-(4sulfophenyl)-2H-tetrazolium 
NMDA

$\mathrm{PAH}$

PBDE

PCB

PND

PODI

ROS

RPF

SD

SEM

SVOC
N-methyl-D-aspartate

Polycyclic aromatic hydrocarbon

Polybromodiphenyl ethers

Polychlorobiphenyls

Postnatal day

Point of departure index

Reactive oxygen species

Relative potency factor

Standard deviation

Standard errors of the means

Semi volatile organic compound

Keywords: Semi volatile organic compounds, benchmark concentrations, mixture, relative toxicity.

\section{Background}

For 50 years now, the emergence of new building materials coupled with increased use of consumer products and electrical and electronic equipment has led to the emission of semi volatile organic compounds (SVOCs) indoors. In this paper we consider SVOCs as defined by Weschler and Nazaroff: "organic compounds with vapor pressures between $10^{-14}$ and $10^{-}$ ${ }^{4} \mathrm{~atm}\left(10^{-9}\right.$ to $\left.10 \mathrm{~Pa}\right)$ " (Weschler and Nazaroff 2008), and which have a boiling point between $240^{\circ}$ and $400^{\circ} \mathrm{C}$ according to French standards (NF ISO 16000-6, 2006). They include, for example, phthalates, polybromodiphenyl ethers (PBDEs), polychlorobiphenyls (PCBs), 
polycyclic aromatic hydrocarbons (PAHs) and various families of pesticides. The widespread use of products containing SVOCs, in association with their physicochemical characteristics, leads to their omnipresence (and sometimes persistent presence) in both air and settled dust (Mercier et al., 2011). Numerous SVOCs are known to be neurotoxic in experimental mammals, and questions arise as to their potential effects in humans. Most studied SVOCs are organochlorine, organophosphorus and pyrethroid pesticides, since these are produced precisely for their neurotoxic properties on insects. High to moderate levels of occupational exposure to these pesticides have been linked with neurobehavioral performance deficits and abnormalities in human nerve function (Kamel and Hoppin 2004), though whether chronic exposure to low (environmental) levels is also neurotoxic remains a matter of some controversy. Several recent epidemiological studies have shown an association between prenatal exposure to pesticides and neurological disorders (decreased IQ scores, cognitive development changes, abnormal reflexes, visual acuity, fine motor skills, attention deficit, hyperactivity) and in particular for organophosphorus (Munoz-Quezada et al. 2013; González-alzaga et al., 2014), pyrethroids (Viel et al. 2015), and organochlorines (Cartier et al., 2014). Prenatal exposure to polychlorobiphenylethers (PCBs) or bisphenol A (BPA) also appears to be related to cognitive impairments, as recently reviewed (Boucher et al. 2009; Polańska et al. 2013; Quinete et al. 2014; Mustieles et al. 2015). Neurodevelopmental deficits were also associated with prenatal exposure to polybromodiphenylethers (PBDEs) (Roze et al. 2009; Herbstman et al. 2010; Eskenazi et al. 2013; Chen et al 2014; Chevrier et al. 2016). The same observations were made of pre- and postnatal exposure to phthalates: prenatal exposure to DEHP and DBP and impaired behavior at 2 and 8 years of age (Polańska et al. 2014; Lien et al. 2015), postnatal DEP and DBP exposure associated with hyperactivity and impairment in adaptive functions (Philippat et al. 2015), and postnatal exposure to DEHP and attention / learning disorders (Chopra et al. 2014). Fewer epidemiological data are available 
for PAHs, but these show similar trends relating to cognitive function impairment (Edwards et al. 2010; Perera et al. 2011, Jedrychowski et al. 2015).

Experimental data confirm the neurotoxic potency of these SVOCs, especially on the developing brain, and support the biological plausibility of associating SVOC exposure with neurobehavioral disorders. Pre and/or postnatal exposures in rodents lead to: delayed spatial learning for BDE-99 (Blanco et al. 2013), decreased learning ability and memory for BDE153 (Zhang et al., 2013) and benzo(a)pyrene (BaP) (Cheng et al. 2013; Chepelev et al. 2015), decreased motor activity for BDE-47 (Ta et al. 2011), and behavioral disturbance for a mixture of 6 PCBs (Elnar et al. 2012), BPA (Viberg and Lee, 2011) and fluorene (Peiffer et al. 2013), and attention deficit and hyperactivity for PCB-153 (Johansen et al. 2014) or phthalates (Miodovnik et al. 2014). Numerous critical reviews have already been published on the neurotoxicity of SVOCs in recent years, such as persistent SVOCs (PCB or PBDE) (Berghuis et al. 2015), pesticides (Burns et al. 2013; Mostafalou and Abdollahi 2017), phthalates (Miodovnik et al. 2014), PAHs (Wormley et al. 2004) or more broadly, endocrine disrupting compounds (Masuo et al. 2011). The main conclusions show neurodevelopmental outcomes for most SVOCs studied, with a large body of evidence for PCBs, PBDEs or pesticides (which are especially organophosphorus). While few or no epidemiological studies are available for PAHs, phthalates or some BPAs, supporting animal data provide potential evidence of their neurotoxicity.

These findings raise the question of the public health impact of SVOCs in general, which may be simultaneously present in indoor environments, thus exposing people to a complex mixture. Cumulative risk assessment could be used to assess this public health issue. A variety of methodologies have already been applied, and these have recently been reviewed (Fournier et al. 2014b): in practice, 'Hazard Index' (HI), 'Point Of Departure Index' (PODI) and 'Relative Potency Factor' (RPF) approaches are the most commonly used. These 
methodologies assume dose-additivity, based on the principle that synergism is less likely to occur at environmentally relevant low doses (ATSDR 2004; Kortenkamp et al. 2009). HI is the summation of individual hazard quotient for each chemical. The main benefit of the HI approach is its simplicity - which is why it is so broadly used in CRA. Drawbacks are the use of non-comparable toxicity indicators (different critical effects) leading to unsatisfactory results, and an extremely conservative approach. PODI avoids these drawbacks by directly comparing exposure to a toxicity indicator (POD) retrieved from the literature (a NOAEL, a LOAEL or a BMDL). However, because there is no guarantee that the POD for a given effect will necessarily be available in the literature, a reduced number of compounds can be studied. The RPF approach converts exposure into an index chemical equivalent by scaling the dose of each SVOC by its toxicity relative to the index chemical. This relies on both the existence of high quality dose-response data and a common mechanism of action for the SVOCs in question. The RPF approach demands more data on each chemical than do the other approaches. PODI and RPF have already been proposed for certain SVOCs such as pyrethroids, organophosphorus, phthalates, PAHs, fungicides and perfluorinated compounds ( Borg et al. 2013; Audebert et al. 2012; Kortenkamp and Faust 2010; US EPA 2006; Wolansky et al. 2006). The approaches cannot however be used together in a single cumulative risk assessment, because they are not based on the same endpoints (reproductive or hepatic endpoints, anti-androgenic or genotoxic mechanisms, decrease in acetylcholinesterase or motor activity, chronic or acute exposure, etc...).

The cumulative risk assessment issue is challenging, and a consensus has been reached that hierarchical approaches should be adopted, each tier being more refined than the previous one (Meek et al. 2011). Instead of using a traditional reference dose based on a common target (as may be extracted from the US EPA IRIS database for some organs/systems, including the nervous system), we propose to complete the "tier 0 approach" recommended by Meek et al. 
(2011) using a less conservative approach, based on relative toxicity. The choice of a common outcome with sufficient comparable toxicity data was based on a previous work identifying neuronal death (Fournier et al. 2014) as a consequence of exposure to numerous SVOCs. Impairment of cognitive function may be linked, in part, to neuronal death, as has been suggested by several authors (Sharma et al. 2009; Lahouel et al. 2016). Neuronal death may be due to different mechanisms such as those involving oxidative stress (Grova et al. 2007; Dominico et al. 2002; Bouayed et al. 2009; Rammal et al. 2010), disruption of calcium signaling or modification of the expression of proteins required for brain development (Yuan et al. 2003). Neuronal death may be a consequence of various signaling pathways, one of which is apoptosis (Davis and Williams 2012; Green and Kroemer 2004; Niizuma et al. 2009) as shown in Figure 1. It induces activation of different proteins, such as the cell surface death receptor, $\mathrm{Bcl} 2, \mathrm{BH} 3$ (a proapoptotic $\mathrm{Bcl} 2$ family member), Bax (proapoptotic $\mathrm{Bcl} 2$ associated X protein), caspases, AIF (apoptosis-inducing factor) or cytochrome C (Cyt C) (Davis and Williams 2012). Some SVOCs (PBDEs, organochlorines, organophosphorus pesticides, or PAHs in particular) may induce activation of such proteins (Karami-Mohajeri and Abdollahi 2011; Kodavanti et al. 2015; Mariussen and Fonnum 2006; Zhang et al. 2015; Costa et al. 2016; He et al. 2016).

The aim of this work is to estimate the relative toxicity of the indoor SVOCs that were found simultaneously in French dwellings, using comparable benchmark concentrations (BMCs) based on neuronal death.

\section{Material and Method}

\subsection{Selection and grouping of indoor SVOCs}


The selection of chemicals was based on recent measurement campaigns in French dwellings in a range of environmental media (air, gas phase or particle matter and settled dust) (Mandin et al., 2013, 2016; Blanchard et al., 2014). 66 compounds were selected from a previous ranking on the basis of contamination data and reference doses (Bonvallot et al., 2010). SVOCs were included in the present work when they were detected in more than $10 \%$ of the dwellings investigated (from 30 to 285 , according to the campaign). SVOC grouping was based on an approach previously described (Fournier et al. 2014a). For each chemical, an initial hazard identification was performed by means of a literature review covering its neurotoxic effects in humans and other mammals. As well as being of high enough quality to be taken into consideration, studies should describe at least one adverse effect on the neurological system, regardless of the experimental system used. SVOCs were then grouped by common key events, when known (Fournier et al. 2014a). An update of this work enabled selection of a group of SVOCs based on neuronal death as a common endpoint, taking into consideration the potential relationship between neuronal death and disturbance to neurobehavioral abilities (Sharma et al. 2009; Lahouel et al. 2016; Grova et al. 2007; Dominico et al. 2002; Bouayed et al. 2009; Rammal et al. 2010). In compliance with European Food Safety Authority (EFSA) recommendations, the present work takes into account contaminants from different chemical families, having a variety of mechanisms of action, provided they produce a common impact on the same target cell (EFSA 2013). EFSA recommends this approach for the assessment of the cumulative risks of pesticide residues in food.

\subsection{Benchmark Concentration (BMC) derivation}


BMCs were derived using the following steps: i) selection of endpoint; ii) selection of suitable dose-response datasets; iii) choice of level of response associated with the BMC; iv) fitting models to experimental data and v) selection of the best fitting model.

Selection of endpoint: Several types of cell death exist, including apoptosis and necrosis. In this work, depending on data availability, cell viability assays may represent an advanced state of cell degeneration. Many methods for the assessment of neuronal cell viability have been developed (Aras et al. 2008). Most are based on measurement of metabolic (mitochondrial) activity, or on membrane integrity as a proxy of cell viability. The MTT (3(4,5-dimethylthiazol-2-yl)-2,5-diphenyltetrazolium bromide) assay was preferred because it is the one most frequently used as a proxy for cell viability measurement.

Selection of suitable dose-response datasets: For each SVOC, dose-response datasets were collected and selected on the basis of a compromise between the amount of available data and comparability of the data between compounds. Preferences were:

- In vitro test system: cell line, neurons, human

- Experimental design: 3 dose-levels and 1 control (4 groups)

- Exposure duration: 24 to 48 hours

- Result expression: raw data availability and standard deviation.

When not provided by the authors, raw data and Standard Deviations (SDs) were obtained using a graphical estimation, as described by the US EPA (US EPA 2005). Where only Standard Errors of the Means (SEMs) were given, these were converted to SDs using the following equation: $S D=S E M \times \sqrt{n}$, where $\mathrm{n}$ is the sample size.

Choice of level of response associated with the BMC: The benchmark responses (or BMRs) selected are the default values recommended by the US EPA (that is, one SD in relation to the control for continuous responses, or a $10 \%$ response rate for dichotomous responses). 
Selection of the best fitting model: BMCs were computed using PROAST software (www.rivm.nl/proast v38.9). As suggested by Levasseur, the Hill family models were selected for modeling of the dose-response relationships(Levasseur et al. 1998). Cells are considered mutually dependent - therefore responses measured from in vitro data could be considered continuous. The Hill models family is presented below in Equations 1 to 4 (2 to 4 parameters):

$$
\begin{aligned}
& y=a\left(1-\frac{x}{b+x}\right) \\
& y=a\left(1-\frac{x^{d}}{b^{d}+x^{d}}\right) \\
& y=a\left(1+\frac{(c-1) x}{b+x}\right) \\
& y=a\left(1+\frac{(c-1) x^{d}}{b^{d}+x^{d}}\right)
\end{aligned}
$$

Where $x$ is toxic compound concentration, $a$ is the background response, $b$ is the concentration of the compound inducing $50 \%$ of the effect, $d$ is the slope, and $a^{*} c$ is the response to an infinite dose.

Selection of the best fitting model: The best fitting model from the Hill family was selected according to the procedure described by Slob (Slob 2002), using the likelihood ratio test. To compare contaminant toxicity, the central estimation (BMC) was used in preference over the BMCL (Benchmark Concentration Lower Bound $=$ lower limit of a one-sided confidence interval on the BMC) which integrates uncertainty of experimental data, as suggested by the US EPA in 2010 (US EPA 2010).

\section{Results}

\subsection{Grouping of indoor SVOCs}


58 SVOCs were selected, since these were detected in at least $10 \%$ of dwellings (Table I). Of these, 28 were documented as having different neurotoxic properties, inducing neurobehavioral effects in mammals or humans. In 21 cases, neuronal death was hypothesized on the basis of viability assays. This outcome was caused by different upstream key events leading to membrane alteration (for $11 \mathrm{SVOCs}$ ), mitochondrial impairment (for $17 \mathrm{SVOCs}$ ) or neurotransmitter modulation (for 7 SVOCs), as shown in Figure 2. Neuronal death is the endpoint that includes the highest number of SVOCs (Fournier et al. 2014a) with exploitable dose/ concentration-response data, and is thus retained for the derivation of BMCs. For example, only 11 chemicals have at least 3 dose groups based on in vivo neurobehavioral changes with different responses measured (i.e. spatial learning and memory, anxiety or motor coordination).

\subsection{Benchmark concentrations derivation}

Concentration-response relationships fulfilling our criteria were available for 15 of the 21 SVOCs selected. Six contaminants (triclosan, 4,4'-DDT, DBP, DiBP, BDE-153 and permethrin) were excluded because there was no available concentration-response relationship in cell viability assays. Table II briefly summarizes the concentration-response data for each compound. Each response and standard deviation was converted into percentage of control. Concentration-response data were obtained from different species: rats $(6 / 15)$, mice $(4 / 15)$ or humans $(5 / 15)$, usually on cell lines $(12 / 15)$, and exposed for 24 to 48 hours (14/15). Only 3 experiments used primary culture in neonatal or prenatal rats.

The response measured in the toxicological studies was a decrease in cell viability estimated using 5 different tests corresponding to 2 measurements: membrane integrity (Trypan Blue dye assay), and mitochondrial activity (resazurin (CellTiter-Blue kit), MTT, MTS (3-(4,5dimethylthiazol-2-yl)-5-(3-carboxymethoxyphenyl)-2-(4-sulfophenyl)-2H-tetrazolium) and 
CCK-8 (Cell Counting Kit-8) assays). Mitochondrial activity was thus measured in more than $90 \%$ of cases (14/15 SVOCs).

$\mathrm{BMC}_{10}$, corresponding to a $10 \%$ decrease in neuronal viability, were presented in Table III. The number of parameters used for Hill equations ranged from 2 to 4 . Resulting BMCs 10 range from 0.072 to $94.35 \mu \mathrm{M}$, corresponding to approximatively 3 orders of magnitude. Because no dose-response models fit their dataset, it was not possible to model the BPA and PCB-118 BMC $_{10}$. Indeed, BPA had a non-monotonic curve and PCB-118 had a response decreasing by more than $30 \%$ from the first tested dose.

Figure 3 shows the relative toxicity of the 13 different SVOCs based on the central estimation (BMC) and the lower and upper 90\%-confidence bounds (BMCL and BMCU respectively). According to these BMC central estimations, we can distinguish three groups of compounds:

1) BMC below $1 \mu \mathrm{M}$ with PCB-153 alone which appears the most toxic for the endpoint considered (cell viability); 2) BMCs between 1 and $10 \mu \mathrm{M}$ : deltamethrin, B(a)P, BDE-47, BDE-209, BDE-99 and PCB-77; 3) BMCs between 10 to $100 \mu \mathrm{M}$ : DEHP, dieldrin, chlorpyrifos, lindane, PCB-52 and diazinon.

\section{Discussion and conclusion}

Carrying out a CRA is currently a challenging matter. Some authors suggested the adoption of hierarchical approaches, with each tier being more refined than the last (Meek et al. 2011). In addition to the tier-0 HI approach (based on existing reference doses) we present elements for a first-tier approach based on relative toxicities estimated from data that is as comparable as possible. One way to do so is through the use of in vitro assays, which are standardized and widely available. In this way, we derived BMCs for 13 SVOCs pertaining to various chemical families to which people are exposed in indoor environments. We were able to rank 3 PCBs, 
5 pesticides, 3 PBDEs, 1 phthalate, and $1 \mathrm{PAH}$, according to their ability to decrease neuronal cell viability as observed in vitro.

BMCs were modeled from published dose-response relationships. The raw data differ in various aspects: 8 different cell lines, 3 different species strains, 3 distinct windows of exposure, 5 neuronal viability assays and 4 different durations of exposure.

In our work, studies based on human cells were preferred, but choice was limited by the availability of exploitable and reliable studies in the literature. Different human, rat and mouse cell lines were therefore used (Table II). However, the species tested do not seem to affect the BMC calculation, as shown by Goldoni et al. who tested the same toxicants on different cell lines from both rats and humans (Goldoni et al. 2003). They showed that different cell lines from the same species are capable of reacting differently to the same compound, using the same neuronal viability test (here the MTT test). For rats, they showed that C6 cells were more resistant to styrene oxide than PC12 cells. Similarly, in humans, D384 cells were more resistant to styrene oxide than SK-N-MC cells. In our work, the cells came from different strains (mice, rats and humans) and were from different cell lines for mice (hypothalamic and neuroblastoma cells, named GT1-7 and Neuro-2a respectively), rats (dopaminergic and pheochromocytoma cell, named N27 and PC-12 respectively or hippocampal and cortical neurons taken directly from the exposed animals), or humans (neuroblastoma cell from SK-N-MC and SH-SY5Y cell lines). Potency ranking could therefore be affected by the different cell lines used in these experiments.

As with the cell lines and species, selected studies also vary in their use of different neuronal viability assays. The MTT assay estimates cellular viability through measurement of mitochondrial dehydrogenase activity. This is the most widely used assay (more than $50 \%$ of our study SVOCs). We chose to also include studies using other kinds of neuronal viability assays: MTS (also known as CCK-8) and rezasurin assays (known as CellTiter-Blue assays) 
which also assess metabolic activity and are sensitive to the function of mitochondrial enzymes, which lose activity early in progression towards death (Aras et al. 2008), and the Trypan Blue assay, which assesses neuronal membrane integrity. The Trypan Blue method is based on the principle that live (viable) cells do not take up certain dyes, whereas dead (nonviable) cells do (Strober 2001). This is the least sensitive of the assays. The MTS assay appears easier to use, faster and slightly more sensitive than MTT. The resazurin assay appears to be more sensitive than the tetrazolium assays (MTS and MTT) (Riss et al. 2013). We can consider the following order of sensitivity for the various assays: Trypan Blue < MTT $\approx$ MTS $(\mathrm{CCK}-8)<$ resazurin $($ CellTiter-Blue). This difference in sensitivity might also affect the rank of potency of the tested SVOCs. The most toxic SVOC of the group was PCB-153, which was tested using the resazurin test. PCB-52, the second least toxic compound in this work, was tested using Trypan Blue. Without testing cell viability with other tests (MTT or MTS), it is difficult to assess whether their toxicity, relative to the others, is due to the sensitivity of the assays used or to their real ability to decrease cell viability. In addition, it is important to note that there is no guarantee that the decrease in metabolic activity is necessarily irreversible in MTT/MTS or resazurin assays. It is therefore not possible to demonstrate a direct link between metabolic activity, cell viability and neuronal death. Nevertheless, this parameter would only change the order of potencies for this group of contaminants.

As underlined by Deshpande et al., duration of exposure could also influence the calculated BMCs. These show a linear and time-dependent increase in neuronal cell death linked to extracellular calcium entering cells through the N-methyl-D-aspartate (NMDA) glutamate receptor channel (Deshpande et al. 2008). The studies retained in our work are also based on various exposure durations (5 hours to 48 hours). According to Deshpande's conclusion, one might expect lengthier exposure of cells to be more lethal - yet this was not confirmed in our 
data. In fact, dieldrin, lindane and diazinon appeared to be the least toxic compounds in spite of longer cell exposure. On the other hand, PCB-77 appeared to be 10 times more potent than diazinon after 5 hours of exposure (as against 48 hours for diazinon).

These relative toxicities could be used for cumulative risk assessment of real indoor mixtures of contaminants. Because they are based on in vitro data, these results should however be interpreted with caution. An important limitation is the absence of bioaccumulation data in short-term assays, while 9 SVOCs are persistent in the human body (PCB-153, B(a)P, BDE47, BDE-99, BDE-209, PCB-77, dieldrin, lindane and PCB-52). Metabolic transformation has not been taken into account, since most in vitro studies test parent compounds. In our work, only $\mathrm{B}(\mathrm{a}) \mathrm{P}$ was tested using the $\mathrm{S} 9$ fraction in order to be metabolized.

Another potential confounder is that SVOCs are ubiquitous compounds; they can contaminate the labs in which the experiments are conducted. Control groups may thus differ across experiments, leading to a lack of comparability for the effect of treatment and statistical significance across SVOCs. This is particularly true of phthalates or bisphenols.

In addition, the use of such indicators should not prevent implementation of chemical-bychemical risk assessment and "tier-0" cumulative risk assessment (i.e. HI) based on a larger biological scale (for example in vivo neurobehavioral changes), since neurotoxicity may be due to different mechanisms not necessarily leading to neuronal death. It is difficult to compare in vivo and in vitro data, because such studies do not share the same objectives. Two in vivo studies with $\mathrm{BMD}_{10}$ were found in the literature, for $\mathrm{B}(\mathrm{a}) \mathrm{P}$ (Chepelev et al. 2015) and BDE-47 (Yan et al. 2012). In these cases, the authors measured spatial learning and memory in orally exposed Sprague Dawley rats, using the Morris Water Maze test. B(a)P was tested postnatally of a period of 7 days (doses from 0.2 to $2 \mathrm{mg} / \mathrm{kg} / \mathrm{d}$ ) and BDE-47 was tested at the adult age over a period of 30 days (doses from 0.1 to $1 \mathrm{mg} / \mathrm{kg} / \mathrm{d}$ ). In vivo $\mathrm{BMDs}_{10}$ were respectively 0.049 and 0.039 [CI90: $0.029-0.054] \mathrm{mg} / \mathrm{kg} / \mathrm{d}$ for B(a)P and BDE-47. As a 
result, the in vivo relative toxicity of BDE- 47 was found to be the same as $\mathrm{B}(\mathrm{a}) \mathrm{P}$ when studying spatial learning and memory, while it was 2 times less potent when studying in vitro cell viability. This difference might be related to the existence (beside neuronal death) of other toxicity pathways leading to neurobehavioral impact, such as interaction with the synaptic transmission (through potentiation of the GABAergic signaling pathway and inhibition of acetylcholine signaling, (Hendriks et al. 2010)) or interaction with the thyroid metabolism (Abdelouahab et al. 2009). It may also be related to the differences in in vivo experimental protocols, which can lead to inconsistencies in potency estimation - as demonstrated by Wolansky and Tornero-Velez (2013) for pyrethroids.

Lastly, the most important limitation of this work is the lack of available and comparable data in the scientific literature: of the initial 58 SVOCs detected in more than $10 \%$ of the French dwellings that had been investigated, 50\% are documented as neurotoxic (Figure 2). Of these, $28 \%$ were excluded because no study focused on neuronal death, $20 \%$ because there was no dose-response relationship, and $7 \%$ because there was no suitable dose-response model. This was also recently underlined by Wignall et al. in their standardization of BMD calculations (Wignall et al. 2014). This team sought to apply a standardized process to the conduct of BMD modeling, to reduce inconsistencies in model fitting and selection. They identified 1,260 chemicals having at least one toxicity value, then applied a curation of chemicals and data in order to remove mixtures, chemicals missing structural information, and inorganic, organometallic, and duplicate structures. In the process of this curation, 374 chemicals were dropped. Of the 886 remaining chemicals, dose-response data was available for just 352 . This corresponds to $28 \%$ of the initial chemicals.

The originality of this work lies in its grouping of compounds from the different chemical families people really are exposed to. Based on the methodological limitations mentioned, we particularly recommend the standardization of experimental protocols and the publication of 
results according to a format adapted for dose-response relationship modeling - both for in vitro and in vivo studies, given the pros and cons of such experiments. This will be needed to reduce uncertainty when using this type of indicators in a risk assessment context.

\section{Funding information}

This work was supported by the French Ministry of Ecology: Primequal [Environnement Intérieur et Approches Innovantes], programme 190, THUR-BSAF action 13, sub-action 08, contract N²12-MRES-PRIMEQUAL-1-CVS-06

\section{Author's contributions}

KF developed the first study outline which was extended in collaboration with EB. The results were discussed and interpreted by KF and NB. PG and DZ reviewed and contributed to the final version of the manuscript. All authors have approved the final version.

\section{Competing interests}

The authors declare that they have no competing interests. 


\section{References}

Abdelouahab N, Suvorov A, Pasquier J-C, Langlois M-F, Praud J-P, Takser L. 2009. Thyroid disruption by low-dose BDE-47 in prenatally exposed lambs. Neonatology; 96:120-124.

Agarwal S, Yadav A, Tiwari SK, Seth B, Chauhan LK, Khare P, Ray RS, Chaturvedi RK. Dynamin-related protein 1 inhibition mitigates Bisphenol-A mediated alterations in mitochondrial dynamics and neural stem cells proliferation and differentiation. Journal of Biological Chemistry; in press. doi: jbc.M115.709493.

Aras, M. A., Hartnett, K. A. and Aizenman, E. 2008. Assessment of Cell Viability in Primary Neuronal Cultures. Current Protocols in Neuroscience. 44:7.18: 1-15.

ATSDR. 2004. Guidance manual for the assessment of joint toxic action of chemical mixtures.

Audebert M, Zeman F, Beaudoin R, Péry A, Cravedi JP. 2012. Comparative potency approach based on $\mathrm{H} 2 \mathrm{AX}$ assay for estimating the genotoxicity of polycyclic aromatic hydrocarbons. Toxicology and Applied Pharmacology; 260(1):58-64.

Bahrami F, Hashemi M, Khalili F, Hashemi J, Asgari A. 2013. Stimulation of CB1 Cannabinoid and NMDA Receptors Increases Neuroprotective Effect against DiazinonInduced Neurotoxicity. Neurophysiology; 45:433-440.

Beard JD, Umbach DM, Hoppin JA, Richards M, Alavanja MC, Blair A, Sandler DP, Kamel F. 2014. Pesticide exposure and depression among male private pesticide applicators in the agricultural health study. Environmental Health Perspectives; 122(9):984-991.

Berghuis SA, Bos AF, Sauer PJ, Roze E. 2015. Developmental neurotoxicity of persistent organic pollutants: an update on childhood outcome. Arch Toxicol;89(5):687-709.

Blanco J, Mulero M, Heredia L, Pujol A, Domingo JL, Sánchez DJ. 2013. Perinatal exposure to BDE-99 causes learning disorders and decreases serum thyroid hormone levels and BDNF gene expression in hippocampus in rat offspring. Toxicology; 308:122-128. 
Boix J, Cauli O, Felipo V. 2010. Developmental exposure to polychlorinated biphenyls 52, 138 or 180 affects differentially learning or motor coordination in adult rats. Mechanisms involved. Neuroscience;167(4):994-1003.

Bonvallot N, Mandin C, Mercier F, Bot B Le, Glorennec P. 2010. Health ranking of ingested semi-volatile organic compounds in house dust: an application to France. Indoor air; 20:458472.

Borg D, Lund B-O, Lindquist N-G, Håkansson H. 2013. Cumulative health risk assessment of 17 perfluoroalkylated and polyfluoroalkylated substances (PFASs) in the Swedish population. Environment International ; 59:112-123.

Boucher O, Muckle G, Bastien CH. 2009. Prenatal exposure to polychlorinated biphenyls: a neuropsychologic analysis. Environmental Health Perspectives; 117:117-116.

Bouayed J, Rammal H, Soulimani R. 2009. Oxidative stress and anxiety: relationship and cellular pathways. Oxidative Medicine and Cellular Longevity; 2:63-67.

Burns CJ, McIntosh LJ, Mink PJ, Jurek AM, Li AA. 2013. Pesticide exposure and neurodevelopmental outcomes: review of the epidemiologic and animal studies. Journal of Toxicology and Environmental Health. Part B, Critical reviews; 16:127-283.Cartier C, Muckle G, Jacobson SW, Jacobson JL, Dewailly E, Ayotte P, et al. 2014. Prenatal and 5-year p,p-DDE exposures are associated with altered sensory processing in school-aged children in Nunavik: A visual evoked potential study. Neurotoxicology; 44: 8-16.

Chen J, Liufu C, Sun W, Sun X, Chen D. 2010. Assessment of the neurotoxic mechanisms of decabrominated diphenyl ether (PBDE-209) in primary cultured neonatal rat hippocampal neurons includes alterations in second messenger signaling and oxidative stress. Toxicology Letters; 192:431-439. 
Chen N-N, Luo D-J, Yao X-Q, Yu C, Wang Y, Wang Q, et al. 2012. Pesticides induce spatial memory deficits with synaptic impairments and an imbalanced tau phosphorylation in rats. Journal of Alzheimer's disease; 30:585-594.

Chen A, Yolton K, Rauch SA, Webster GM, Hornung R, Sjödin A, Dietrich KN, Lanphear BP. 2014. Prenatal polybrominated diphenyl ether exposures and neurodevelopment in U.S. children through 5 years of age: the HOME study. Environmental Health Perspectives;122(8):856-862.

Cheng S, Xia Y, He J, Liu X, Chen X, Ding Y, et al. 2013. Neurotoxic effect of subacute benzo(a)pyrene exposure on gene and protein expression in Sprague-Dawley rats. Environmental Toxicology and Pharmacology; 36:648-658.

Chepelev NL, Moffat ID, Bowers WJ, Yauk CL. 2015. Neurotoxicity may be an overlooked consequence of benzo[a]pyrene exposure that is relevant to human health risk assessment. Mutation Research / Reviews in Mutation Research; 764:64-89.

Chevrier C, Warembourg C, Le Maner-Idrissi G, Lacroix A, Dardier V, Le Sourn-Bissaoui S, Rouget F, Monfort C, Gaudreau E, Mercier F, Bonvallot N, Glorennec P, Muckle G, Le Bot B, Cordier S. 2016. Childhood exposure to polybrominated diphenyl ethers and neurodevelopment at six years age. Neurotoxicology; 54:81-88.

Chopra V, Harley K, Lahiff M, Eskenazi B. 2014. Association between phthalates and attention deficit disorder and learning disability in U.S. children, 6-15 years. Environmental Research; 128:64-69.

Costa LG, Tagliferri S, Roqué PJ, Pellacani C. 2016. Role of glutamate receptors in tetrabrominated diphenyl ether (BDE-47) neurotoxicity in mouse cerebellar granule neurons. Toxicology Letters; 241:159-166.

Davis RE, Williams M. 2012. Mitochondrial function and dysfunction: an update. Journal of Pharmacology and Experimental Therapeutics; 342:598-607. 
Deshpande LS, Lou JK, Mian A, Blair RE, Sombati S, Attkisson E, et al. 2008. Time course and mechanism of hippocampal neuronal death in an in vitro model of status epilepticus: role of NMDA receptor activation and NMDA dependent calcium entry. European Journal of Pharmacology; 583:73-83.

Dickerson SM, Guevara E, Woller MJ, Gore AC. 2009. Cell death mechanisms in GT1-7 GnRH cells exposed to polychlorinated biphenyls PCB74, PCB118, and PCB153. Toxicology and Applied Pharmacology; 237:237-45.

Dominico P, Christopher MC, Feyan L, Verginia Y. 2002. Increased of brain oxidative stress in mild cognitive impairment. Archives of Neurology; 59:972-976.

Edwards SC, Jedrychowski W, Butscher M, Camann D, Kieltyka A, Mroz E et al. 2010. Prenatal Exposure to air borne polycyclic aromatic hydrocarbons and children's intelligence at 5 years of age in a prospective study in Poland. Environmental Health Perspectives; 118:1326-1331.

EFSA. 2013. Scientific Opinion on the relevance of dissimilar mode of action and its appropriate application for cumulative risk assessment of pesticides. EFSA Journal; 11(12):3472.

Elnar AA, Diesel B, Desor F, Feidt C, Bouayed J, Kiemer AK, et al. 2012. Neurodevelopmental and behavioral toxicity via lactational exposure to the sum of six indicator non-dioxin-like-polychlorinated biphenyls ( $\sum 6$ NDL-PCBs) in mice. Toxicology; 299:44-54.

Elwan MA, Richardson JR, Guillot TS, Caudle WM, Miller GW. 2006. Pyrethroid pesticideinduced alterations in dopamine transporter function. Toxicology and Applied Pharmacology; 211:188-197. 
Eriksson P, Fischer C, Fredriksson A. 2006. Polybrominated diphenyl ethers, a group of brominated flame retardants, can interact with polychlorinated biphenyls in enhancing developmental neurobehavioral defects. Toxicological Science;94(2):302-309.

Eshleman AJ, Murray TF. 1991. Pyrethroid insecticides indirectly inhibit GABA-dependent $36 \mathrm{Cl}-$ influx in synaptoneurosomes from the trout brain. Neuropharmacology ; 30:13331341.

Eskenazi B, Chevrier J, Rauch SA, et al. 2013. In utero and childhood polybrominated diphenyl ether (PBDE) exposures and neurodevelopment in the CHAMACOS study. Environmental Health Perspectives; 121:257-262.

Fan Y, Ding S, Ye X, Manyande A, He D, Zhao N, et al. 2013. Does preconception paternal exposure to a physiologically relevant level of bisphenol A alter spatial memory in an adult rat? Hormones and Behavior; 64:598-604.

Farag AT, Radwan AH, Sorour F, Okazy A El, El-Agamy E-S, El-Sebae AE-K. 2010. Chlorpyrifos induced reproductive toxicity in male mice. Reproductive Toxicology; 29:80-85. Faro LRF, Alfonso M, Cervantes R, Durán R. 2009. Comparative effects of pesticides on in vivo dopamine release in freely moving rats. Basic and Clinical Pharmacology and Toxicology; 105:395-400.

Farzanehfar V, Naderi N, Kobarfard F, Faizi M. 2016. Determination of dibutyl phthalate neurobehavioral toxicity in mice. Food and Chemical Toxicology;94:221-226.

Fournier K, Glorennec P, Bonvallot N. 2014a. An exposure-based framework for grouping pollutants for a cumulative risk assessment approach: Case study of indoor semi-volatile organic compounds. Environmental Research; 130:20-28.

Fournier K, Glorennec P, Bonvallot N. 2014b. Derivation of toxicological reference values for taking mixtures into account in health risk assessment: Existing methods and recent applications. Environnement, Risques \& Santé ; 13:203-221. 
Goldoni M, Vettori MV, Alinovi R, Caglieri A, Ceccatelli S, Mutti A. 2003. Models of neurotoxicity: extrapolation of benchmark doses in vitro. Risk Analysis; 23:505-514.

González-Alzaga B, Lacasaña M, Aguilar-Garduño C, Rodríguez-Barranco M, Ballester F, Rebagliato M, et al. 2014. A systematic review of neurodevelopmental effects of prenatal and postnatal organophosphate pesticide exposure. Toxicology Letters; 230:104-121.

Green DR, Kroemer G. 2004. The pathophysiology of mitochondrial cell death. Science; 305(5684):626-629.

Grova N, Valley A, Turner JD, Morel A, Muller CP, Schroeder H. 2007. Modulation of behavior and NMDA-R1 gene mRNA expression in adult female mice after sub-acute administration of benzo(a)pyrene. Neurotoxicology; 28:630-636.

He W, He P, Wang A, Xia T, Xu B, Chen X. 2008. Effects of PBDE-47 on cytotoxicity and genotoxicity in human neuroblastoma cells in vitro. Mutation Research; 649:62-70.

He J, Ji X, Li Y, Xue X, Feng G, Zhang H, Wang H, Gao M. 2016. Subchronic exposure of benzo(a)pyrene interferes with the expression of Bcl-2, Ki-67, C-myc and p53, Bax, Caspase3 in sub-regions of cerebral cortex and hippocampus. Experimental Toxicology and Pathology; 68(2-3):149-156.

Hendriks HS, Antunes Fernandes EC, Bergman A, Berg M van den, Westerink RHS. 2010. PCB-47, PBDE-47, and 6-OH-PBDE-47 differentially modulate human GABAA and alpha4beta2 nicotinic acetylcholine receptors. Toxicological Sciences; 118:635-642.

Herbstman JB, Sjodin A, Kurzon M, et al. 2010. Prenatal exposure to PBDEs and neurodevelopment. Environmental Health Perspectives; 118:712-719.

Holahan MR, Smith CA. 2015. Phthalates and neurotoxic effects on hippocampal network plasticity. Neurotoxicology; 48:21-34.

Jedrychowski WA, Perera FP, Camann D, Spengler J, Butscher M, Mroz E, Majewska R, Flak E, Jacek R, Sowa A. 2015. Prenatal exposure to polycyclic aromatic hydrocarbons and 
cognitive dysfunction in children. Environmental Science Pollution Research International; 22(5):3631-3639.

Jin Y, Liu Z, Peng T, Fu Z. 2015. The toxicity of chlorpyrifos on the early life stage of zebrafish: A survey on the endpoints at development, locomotor behavior, oxidative stress and immunotoxicity. Fish \& Shellfish Immunology; 43:405-414.

Johansen EB, Fonnum F, Lausund PL, Walaas SI, Bærland NE, Wøien G, et al. 2014. Behavioral changes following PCB 153 exposure in the spontaneously hypertensive rat - an animal model of Attention-Deficit/ Hyperactivity Disorder. Behavioral and Brain Functions; $10: 1$

Johansson N, Viberg H, Fredriksson a, Eriksson P. 2008. Neonatal exposure to decabrominated diphenyl ether (PBDE 209) causes dose-response changes in spontaneous behaviour and cholinergic susceptibility in adult mice. Neurotoxicology; 29:911-919.

Kajta M, Litwa E, Rzemieniec J, Wnuk A, Lason W, Zelek-Molik A, et al. 2014. Isomernonspecific action of dichlorodiphenyltrichloroethane on aryl hydrocarbon receptor and Gprotein-coupled receptor 30 intracellular signaling in apoptotic neuronal cells. Molecular and Cellular Endocrinology; 392:90-105.

Kamel F, Hoppin JA. 2004. Association of pesticide exposure with neurologic dysfunction and disease. Environmental Health Perspectives 112:950-958.

Karami-Mohajeri S, Abdollahi M. 2011. Toxic influence of organophosphate, carbamate, and organochlorine pesticides on cellular metabolism of lipids, proteins, and carbohydrates: A systematic review. Human \& Experimental Toxicology; 30:1119-1140.

Karen DJ, Li W, Harp PR, Gillette JS, Bloomquist JR. 2001. Striatal dopaminergic pathways as a target for the insecticides permethrin and chlorpyrifos. Neurotoxicology; 22:811-817. 
Ki Y-W, Park JH, Lee JE, Shin IC, Koh HC. 2013. JNK and p38 MAPK regulate oxidative stress and the inflammatory response in chlorpyrifos-induced apoptosis. Toxicology Letters; 218:235-245.

Kitazawa M, Anantharam V, Kanthasamy AG. 2001. Dieldrin-induced oxidative stress and neurochemical changes contribute to apoptopic cell death in dopaminergic cells. Free Radical Biology \& Medicine; 31:1473-1485.

Kodavanti PR, Royland JE, Osorio C, Winnik WM, Ortiz P, Lei L, et al. 2015. Developmental exposure to a commercial PBDE mixture: effects on protein networks in the cerebellum and hippocampus of rats. Environmental Health Perspectives; 123:428-436.

Kortenkamp A, Faust M. 2010. Combined exposures to anti-androgenic chemicals: steps towards cumulative risk assessment. International Journal of Andrology; 33:463-474.

Kortenkamp A, Faust M, Backhaus T. 2009. State of the Art Report on Mixture Toxicity. Final Report. 391p.

Kuriyama SN, Chahoud I. 2004. In utero exposure to low-dose 2,3',4,4',5pentachlorobiphenyl (PCB 118) impairs male fertility and alters neurobehavior in rat offspring. Toxicology; 202:185-197.

Lahouel A, Kebieche M, Lakroun Z, Rouabhi R, Fetoui H, Chtourou Y, Djamila Z, Soulimani R. 2016. Neurobehavioral deficits and brain oxidative stress induced by chronic low dose exposure of persistent organic pollutants mixture in adult female rat. Environmental Sciences and Pollution Research. In press. doi:10.1007/s11356-016-6913-9.

Lakshmana MK, Raju TR. 1994. Endosulfan induces small but significant changes in the levels of noradrenaline, dopamine and serotonin in the developing rat brain and deficits in the operant learning performance. Toxicology; 91:139-150. 
Lee J-Y, Kim J-W, Lim H-S, Joo W-H, Cho Y-K, Moon J-Y. 2005. Changes in antioxidant defense systems by 2,2',5,5'-tetrachlorobiphenyl exposure in neuronal SK-N-MC cells. Toxicology Letters; 157:139-149.

Lee S, Suk K, Kim IK, Jang I-S, Park J-W, Johnson VJ, et al. 2008. Signaling pathways of bisphenol A-induced apoptosis in hippocampal neuronal cells: Role of calcium-induced reactive oxygen species, mitogen-activated protein kinases, and nuclear factor- $-\mathrm{B}$. Journal of Neuroscience Research; 86:2932-2942.

Levasseur LM, Slocum HK, Rustum YM, Greco WR. 1998. Modeling of the timedependency of in vitro drug cytotoxicity and resistance. Cancer Research; 58:5749-5761.

Li X-J, Jiang L, Chen L, Chen H-S, Li X. 2013. Neurotoxicity of dibutyl phthalate in brain development following perinatal exposure: A study in rats. Environmental Toxicology and Pharmacology; 36(2):392-402.

Lien YJ, Ku HY, Su PH, Chen SJ, Chen HY, Liao PC, Chen WJ, Wang SL. 2015. Prenatal exposure to phthalate esters and behavioral syndromes in children at 8 years of age: Taiwan Maternal and Infant Cohort Study. Environmental Health Perspectives; 123(1):95-100.

Lin CH, Chen TJ, Chen SS, Hsiao PC, Yang RC. 2011. Activation of Trim17 by PPAR $\gamma$ is involved in di(2-ethylhexyl) phthalate (DEHP)-induced apoptosis on Neuro-2a cells. Toxicology Letters 206:245-251.

Lynch CD, Jackson LW, Kostyniak PJ, McGuinness BM, Buck Louis GM. 2012. The effect of prenatal and postnatal exposure to polychlorinated biphenyls and child neurodevelopment at age twenty four months. Reproductive Toxicology; 34:451-456.

Ma N, Liu S, Gao P, Cao P, Xu H. 2013. Effect of diisobutyl phthalate on learning and memory behavior and apoptosis of hippocampus cells in mice. Wei Sheng Yan Jiu; 42:57-60. Mandin, C., Mercier, F., Lucas, J.P., Ramalho, O., Blanchard, O., Bonvallot, N., Raffy, G., Gilles, E., Glorennec, P., Le Bot, B., 2014. ECOS-POUSS: a nationwide survey of semi- 
volatile organic compounds in home settled dust. In: Proceeding of Indoor Air Conference, Hong Kong.

Mandin C, Mercier F, Ramalho O, Lucas JP, Gilles E, Blanchard O, Bonvallot N, Glorennec P, Le Bot B. 2016. Semi-volatile organic compounds in the particulate phase in dwellings: A nationwide survey in France. Atmospheric Environment; 136:82-94.

Mariussen E, Fonnum F. 2006. Neurochemical Targets and Behavioral Effects of Organohalogen Compounds: An Update. Critical Reviews in Toxicology; 36:253-289.

Masuo Y, Ishido M. 2011. Neurotoxicity of endocrine disruptors: possible involvement in brain development and neurodegeneration. J Toxicol Environ Health B Crit Rev;14(5-7):346369.

Meek ME, Boobis AR, Crofton KM, Heinemeyer G, Raaij MV, Vickers C. 2011. Risk assessment of combined exposure to multiple chemicals: A WHO/IPCS framework. Regulatory Toxicology and Pharmacology; 60(2):S1-S14.

Mercier F, Glorennec P, Thomas O, Bot B Le. 2011. Organic contamination of settled house dust, a review for exposure assessment purposes. Environmental Science \& Technology; 45:6716-6727.

Meyer D a, Shafer TJ. 2006. Permethrin, but not deltamethrin, increases spontaneous glutamate release from hippocampal neurons in culture. Neurotoxicology;27:594-603.

Min A, Liu F, Yang X, Chen M. 2014. Benzyl butyl phthalate exposure impairs learning and memory and attenuates neurotransmission and CREB phosphorylation in mice. Food and Chemical Toxicology; 71:81-89.

Miodovnik A, Edwards A, Bellinger DC, Hauser R. 2014. Developmental neurotoxicity of ortho-phthalate diesters: review of human and experimental evidence. Neurotoxicology; $41: 112-122$. 
Mostafalou S, Abdollahi M. 2017. Pesticides: an update of human exposure and toxicity. Arch Toxicol;91(2):549-599.

Muñoz-Quezada MT, Lucero BA, Barr DB, Steenland K, Levy K, Ryan PB, et al. 2013. Neurodevelopmental effects in children associated with exposure to organophosphate pesticides: a systematic review. Neurotoxicology;39:158-168.

Mustieles V, Perez-Lobato R, Olea N, Fernandez MF. 2015. Bisphenol A: Human exposure and neurobehavior. Neurotoxicology; 49:174-184.

Nasuti C, Gabbianelli R, Falcioni ML, Stefano A Di, Sozio P, Cantalamessa F. 2007. Dopaminergic system modulation, behavioral changes, and oxidative stress after neonatal administration of pyrethroids. Toxicology ;229:194-205.

Nasuti C, Manuel C, Donatella F, Rosita G, Antonio DS, Serafina CL, et al. 2012. Effects of early life permethrin exposure on spatial working memory and on monoamine levels in different brain areas of pre-senescent rats. Toxicology;303:162-168.

Nie J-S, Zhang H-M, Zhao J, Liu H-J, Niu Q. 2014. Involvement of mitochondrial pathway in benzo[a]pyrene-induced neuron apoptosis. Human and Experimental Toxicology; 33:240250.

Niizuma K, Endo H, Chan PH. 2009. Oxidative stress and mitochondrial dysfunction as determinants of ischemic neuronal death and survival. Journal of Neurochemistry; 109(Suppl):133-138.

Peiffer J, Cosnier F, Grova N, Nunge H, Salquèbre G, Decret M-J, et al. 2013. Neurobehavioral toxicity of a repeated exposure (14 days) to the airborne polycyclic aromatic hydrocarbon fluorene in adult Wistar male rats. PloS One;8:e71413.

Perera FP, Wang S, Vishnevetsky J, Zhang B, Cole KJ, Tang D et al. 2011. Polycyclic aromatic hydrocarbons-aromatic DNA adducts in cord blood and behavior scores in New York City children. Environmental Health Perspectives;119:1176-1181. 
Philippat C, bennett DH, Krakowiak P, Rose M, Hwang HM, Hertz-Picciotto I. 2015. Phthalate concentrations in house dust in relation to autism spectrum disorder and developmental delay in the CHildhood Autism Risks from Genetics and the Environment (CHARGE) study. Environmental Health;14:56.

Polańska K, Jurewicz J, Hanke W. 2013. Review of current evidence on the impact of pesticides, polychlorinated biphenyls and selected metals on attention deficit / hyperactivity disorder in children. International Journal of Occupational Medicine and Environmental Health;26:16-38.

Polańska K, Ligocka D, Sobala W, Hanke W. 2014. Phthalate exposure and child development: the Polish Mother and Child Cohort Study. Early Human Development;90(9):477-485.

Quinete N, Schettgen T, Bertram J, Kraus T. 2014. Occurrence and distribution of PCB metabolites in blood and their potential health effects in humans: a review. Environmental Science and Pollution Research International;21:11951-11972.

Rammal H, Bouayed J, Soulimani R. 2010. A direct relationship between aggressive behavior in the resident/intruder test and cell oxidative status in adult male mice. European Journal of Pharmacology; 627:173-176.

Riss TL, Moravec RA, Niles AL, Benink HA, Worzella TJ, Minor L. 2013. Cell Viability Assays.

Romero A, Ramos E, Castellano V, Martínez MA, Ares I, Martínez M, et al. 2012a. Cytotoxicity induced by deltamethrin and its metabolites in SH-SY5Y cells can be differentially prevented by selected antioxidants. Toxicology in Vitro;26:823-830.

Romero A, Ramos E, Castellano V, Martínez MA, Ares I, Martínez M, et al. 2012b. Cytotoxicity induced by deltamethrin and its metabolites in SH-SY5Y cells can be differentially prevented by selected antioxidants. Toxicology in vitro;26:823-830. 
Roze E, Meijer L, Bakker A, Van Braeckel KN, Sauer PJ, Bos AF. 2009. Prenatal exposure to organohalogens, including brominated flame retardants, influences motor, cognitive, and behavioral performance at school age. Environmental Health Perspectives;117: 1953-1958.

Sánchez-Alonso JA, López-Aparicio P, Recio MN, Pérez-Albarsanz MA. 2003. Apoptosismediated neurotoxic potential of a planar (PCB 77) and a nonplanar (PCB 153) polychlorinated biphenyl congeners in neuronal cell cultures. Toxicology Letters;144: 337349.

Saunders CR, Shockley DC, Knuckles ME. 2003. Fluoranthene-induced neurobehavioral toxicity in F-344 rats. International Journal of Toxicology;22: 263-276.

Sharma H, Zhang P, Barber DS, Liu B. 2010. Organochlorine pesticides dieldrin and lindane induce cooperative toxicity in dopaminergic neurons: role of oxidative stress. Neurotoxicology;31:215-222.

Sharma DR, Sunkaria A, Bal A, Bhutia YD, Vijayaraghavan R, Flora SJS, Gill KD. 2009. Neurobehavioral impairments, generation of oxidative stress and release of pro-apoptotic factors after chronic exposure to sulphur mustard in mouse brain. Toxicology and Applied Pharmacology;240:208-218.

Simmons SL, Cummings JA, Clemens LG, Nunez AA. 2005. Exposure to PCB 77 affects the maternal behavior of rats. Physiological Behavior;84(1):81-86.

Slob W. 2002. Dose-response modeling of continuous endpoints. Toxicological sciences; 66: 298-312.

Soni I, Syed F, Bhatnagar P, Mathur R. 2011. Perinatal toxicity of cyfluthrin in mice: developmental and behavioral effects. Human and Experimental Toxicology 30:1096-1105. Strober W. 2001. Trypan blue exclusion test of cell viability. Current Protocols in Immunology; Appendix 3B. doi:10.1002/0471142735.ima03bs21. 
Szychowski KA, Sitarz AM, Wojtowicz AK. 2015. Triclosan induces Fas receptor-dependent apoptosis in mouse neocortical neurons in vitro. Neuroscience;284:192-201.

Ta TA, Koenig CM, Golub MS, Pessah IN, Qi L, Aronov PA, et al. 2011. Bioaccumulation and behavioral effects of 2,2',4,4'-tetrabromodiphenyl ether (BDE-47) in perinatally exposed mice. Neurotoxicology and Teratology;33:393-404.

Tagliaferri S, Caglieri A, Goldoni M, Pinelli S, Alinovi R, Poli D, et al. 2010. Low concentrations of the brominated flame retardants BDE-47 and BDE-99 induce synergistic oxidative stress-mediated neurotoxicity in human neuroblastoma cells. Toxicology in vitro;24:116-122.

Tully K, Kupfer D, Dopico a M, Treistman SN. 2000. A plasticizer released from IV drip chambers elevates calcium levels in neurosecretory terminals. Toxicology and applied pharmacology;168:183-138.

Tussel JM, Sunno C, Liorens J, Gelp E, Rodriquez FE. 1986. Effect of Lindane on CNS: Behavioral Studies. 1987. In Toxicology of Pesticides: Clinical and Regulatory Perspective. Costa LG, Galli CL, Murphy SD Eds:311-315. ISBN 978-3-642-70898-5

US EPA. 2010. Development of a relative potency factor (RPF) approach for polycyclic aromatic hydrocarbon (PAH) mixtures. In support of Summary Information on the Integrated Risk Information System (IRIS).

US EPA. 2006. Organophosphorus Pesticides Cumulative Risk Assessment - 2006 Update.

US EPA. 2005. Toxicological review of n-hexane. In support of summary information on the integrated risk information (IRIS). EPA/635/R-03/012.

Vale C, Fonfra E, Bujons J, Messeguer A, Rodrguez-Farr E, Suol C. 2003. The organochlorine pesticides $\gamma$-hexachlorocyclohexane (lindane), $\alpha$-endosulfan and dieldrin differentially interact with GABAA and glycine-gated chloride channels in primary cultures of cerebellar granule cells. Neuroscience;117:397-403. 
Viberg H, Fredriksson A, Buratovic S, Eriksson P. 2011. Dose-dependent behavioral disturbances after a single neonatal bisphenol A dose. Toxicology; 290(2-3):187-194.

Viel JF, Warembourg C, Le Maner-Idrissi G, Lacroix A, Limon G, Rouget F, et al. 2015. Pyrethroid insecticide exposure and cognitive developmental disabilities in children: The PELAGIE mother-child cohort. Environment International;82: 69-75.

Weschler CJ, Nazaroff WW. 2008. Semivolatile organic compounds in indoor environments. Atmospheric Environment;42:9018-9040.

Wignall J, Shapiro AJ, Wright F, Woodruff TJ, Chiu W, Guyton KZ, et al. 2014. Standardizing benchmark dose calculations to improve science-based decisions in human health assessments. Environmental health perspectives;122:499-505.

Wojtowicz A, Szychowski KA, Wnuk A, Kajta M. 2016. Dibutyl phthalate (DBP)-induced apoptosis and neurotoxicity are mediated via the aryl hydrocarbon receptor (AhR) but not by estrogen receptor alpha $(\mathrm{ER} \alpha)$, estrogen receptor beta $(\mathrm{ER} \beta)$, or peroxisome proliferatoractivated receptor gamma $(\operatorname{PPAR} \gamma)$ in mouse cortical neurons. Neurotoxicity Research;doi:10.1007/s12640-016-9665-x.

Wolansky MJ, Gennings C, Crofton KM. 2006. Relative potencies for acute effects of pyrethroids on motor function in rats. Toxicological Sciences;89(1):271-277.

Wolansky MJ and Tornero-Velez R. 2013. Crtitical consideration of the multiplicity of experimental and organismic determinants of pyrethroid neurotoxicity: a proof of concept. Journal of Toxicology and Environmental Health Part B;16:453-490.

Wormley DD, Ramesh A, Hood DB. 2004. Environmental contaminant-mixture effects on CNS development, plasticity, and behavior. Toxicol Appl Pharmacol;197(1):49-65.

Xu X, Yang Y, Wang R, Wang Y, Ruan Q, Lu Y. 2015. Perinatal exposure to di-(2ethylhexyl) phthalate affects anxiety- and depression-like behaviors in mice. Chemosphere;124:22-31. 
Yan T, Xiang L, Xuejun J, Chengzhi C, Youbin Q, Xuelan Y, et al. 2012. Spatial learning and memory deficit of low level polybrominated diphenyl ethers-47 in male adult rat is modulated by intracellular glutamate receptors. Journal of Toxicological Sciences;37(2):223-233.

Yoneda T, Hiroi T, Osada M, Asada A, Funae Y. 2003. Non-genomic modulation of dopamine release by bisphenol-A in PC12 cells. Journal of Neurochemistry;87:1499-1508.

Yu K, He Y, Yeung LWY, Lam PKS, Wu RSS, Zhou B. 2008. DE-71-induced apoptosis involving intracellular calcium and the Bax-mitochondria-caspase protease pathway in human neuroblastoma cells in vitro. Toxicological sciences;104(2):341-351.

Yuan Y, Lipinski M, Degterev A. 2003. Diversity in the Mechanisms of Neuronal Cell Death. Neuron ;40 :401-413.

Zhang H, Li X, Nie J, Niu Q. 2013. Lactation exposure to BDE-153 damages learning and memory, disrupts spontaneous behavior and induces hippocampus neuron death in adult rats. Brain research;1517:44-56.

Zhang S, Chen Y, Wu X, Gao H, Ma R, Jiang C, Kuang G, Zhao G, Xia T, Zhang X, Lei R, Zhang C, Li P, Xu C, Wang A. 2015. The pivotal role of $\mathrm{Ca}(2+)$ homeostasis in PBDE-47induced neuronal apoptosis. Molecular Neurobiology:1-11. doi:10.1007/s12035-015-9573-8. 
$\backslash$ Figure 1: The main mitochondrial pathways for cell death (inspired from Davis and Williams 2012)

Bax: proapoptotic Bcl-2-associated X protein; Bak: Bcl-2 homologous antagonist killer; BH3: proapopotoic Bcl-2 family members; Endo G: endonuclease G; FADD: FAD domain protein; Cyt C: cytochrome C; Fas: transmembrane receptor

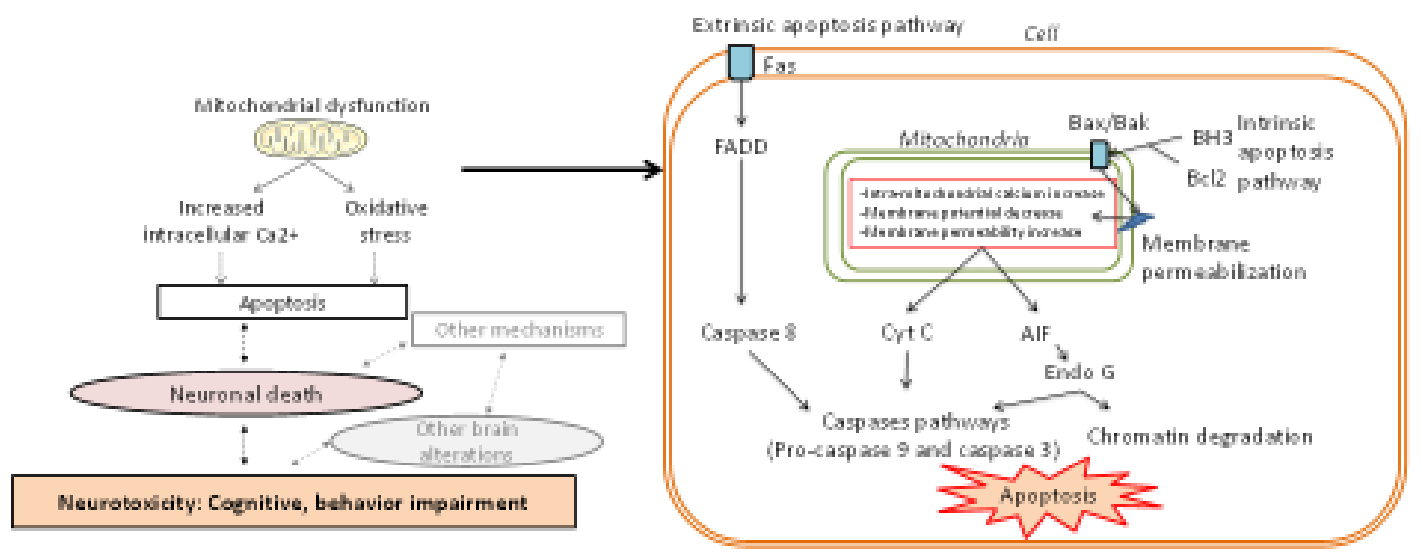




\section{Figure 2: Grouping of 29 indoor Semi Volatile Organic Compounds (SVOCs) based on neuronal death, adapted and updated from (Fournier et al. 2014a).}

${ }^{1}$ (Chopra et al. 2014); ${ }^{2}$ Xu et al. 2015); ${ }^{3}$ (Ma et al. 2013); ${ }^{4}$ (Li et al. 2013); ${ }^{5}$ (Farzanehfar et al. 2016); ${ }^{6}$ (Min et al. 2014); ${ }^{7}$ (Ta et al. 2011); ${ }^{8}$ (Chen et al. 2014); ${ }^{9}$ (Blanco et al. 2013); ${ }^{10}$ (Zhang et al. 2013); ${ }^{11}$ (Johansson et al. 2008); ${ }^{12}$ (Eriksson et al. 2006); ${ }^{13}$ (Boix et al. 2010); ${ }^{14}$ (Simmons et al. 2005); ${ }^{15}$ (Kuriyama and Chahoud 2004); ${ }^{16}$ (Lynch et al. 2012); ${ }^{17}$ (Cheng et al. 2013); ${ }^{18}$ (Johansen et al. 2014); ${ }^{19}$ (Chepelev et al. 2015); ${ }^{20}$ (Peiffer et al. 2013); ${ }^{21}$ (Saunders et al. 2003); ${ }^{22}$ (Viberg et al. 2011); ${ }^{23}$ (Beard et al. 2014); ${ }^{24}$ (Lakshmana and Raju 1994); ${ }^{25}$ (Tussel et al. 1987); ${ }^{26}$ (Burns et al. 2013); ${ }^{27}$ (Soni et al. 2011); ${ }^{28}$ (Nasuti et al. 2007); ${ }^{29}$ (Chen et al. 2012); ${ }^{30}$ (Nasuti et al. 2012); ${ }^{31}$ (Sharma et al. 2010); ${ }^{32}$ (Szychowski et al. 2015); ${ }^{33}$ (Lin et al. 2011); ${ }^{34}$ (Tagliaferri et al. 2010); ${ }^{35}$ (Chen et al. 2010); ${ }^{36}$ (Lee et al. 2005); ${ }^{37}$ (Dickerson et al. 2009); ${ }^{38}$ (Nie et al. 2014); ${ }^{39}$ (Lee et al. 2008); ${ }^{40}$ (Bahrami et al. 2013); ${ }^{41}$ (Ki et al. 2013); ${ }^{42}$ (Romero et al. 2012b); ${ }^{43}$ (Elwan et al. 2006); ${ }^{44}$ (Kajta et al. 2014); ${ }^{45}$ (Yu et al. 2008); ${ }^{46}$ (Faro et al. 2009); ${ }^{47}$ (Kitazawa et al. 2001); ${ }^{48}$ (Karen et al. 2001); ${ }^{49}$ (Yoneda et al. 2003); ${ }^{50}$ (He et al. 2008); ${ }^{51}$ (Tully et al. 2000); ${ }^{52}$ (Meyer and Shafer 2006); ${ }^{53}$ (Jin et al. 2015); ${ }^{54}$ (Fan et al. 2013); ${ }^{55}$ (Farag et al. 2010); ${ }^{56}$ (Vale et al. 2003); ${ }^{57}$ (Eshleman and Murray 1991); ${ }^{58}$ (Agarwal et al. 2016); ${ }^{59}$ (SanchezAlonso et al. 2003) ; ${ }^{60}$ (Wójtowicz et al. 2016).

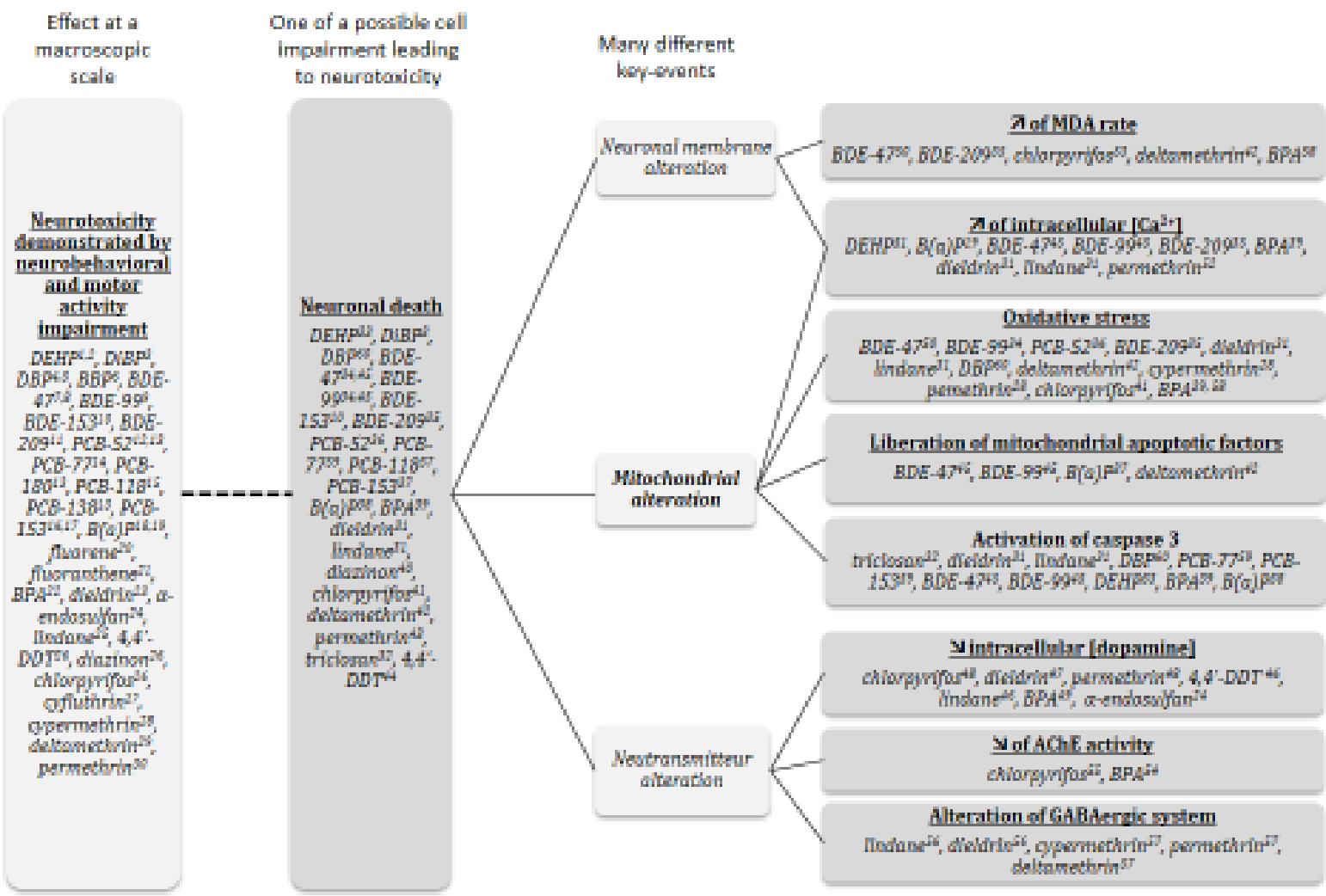


Figure 3: Comparable BMC10 for 13 indoor Semi Volatile Organic Compounds (SVOCs)

Each $B M C_{10}$ in represented by a black line, BMCL is below (red line) BMC, and BMCU is above (green line).

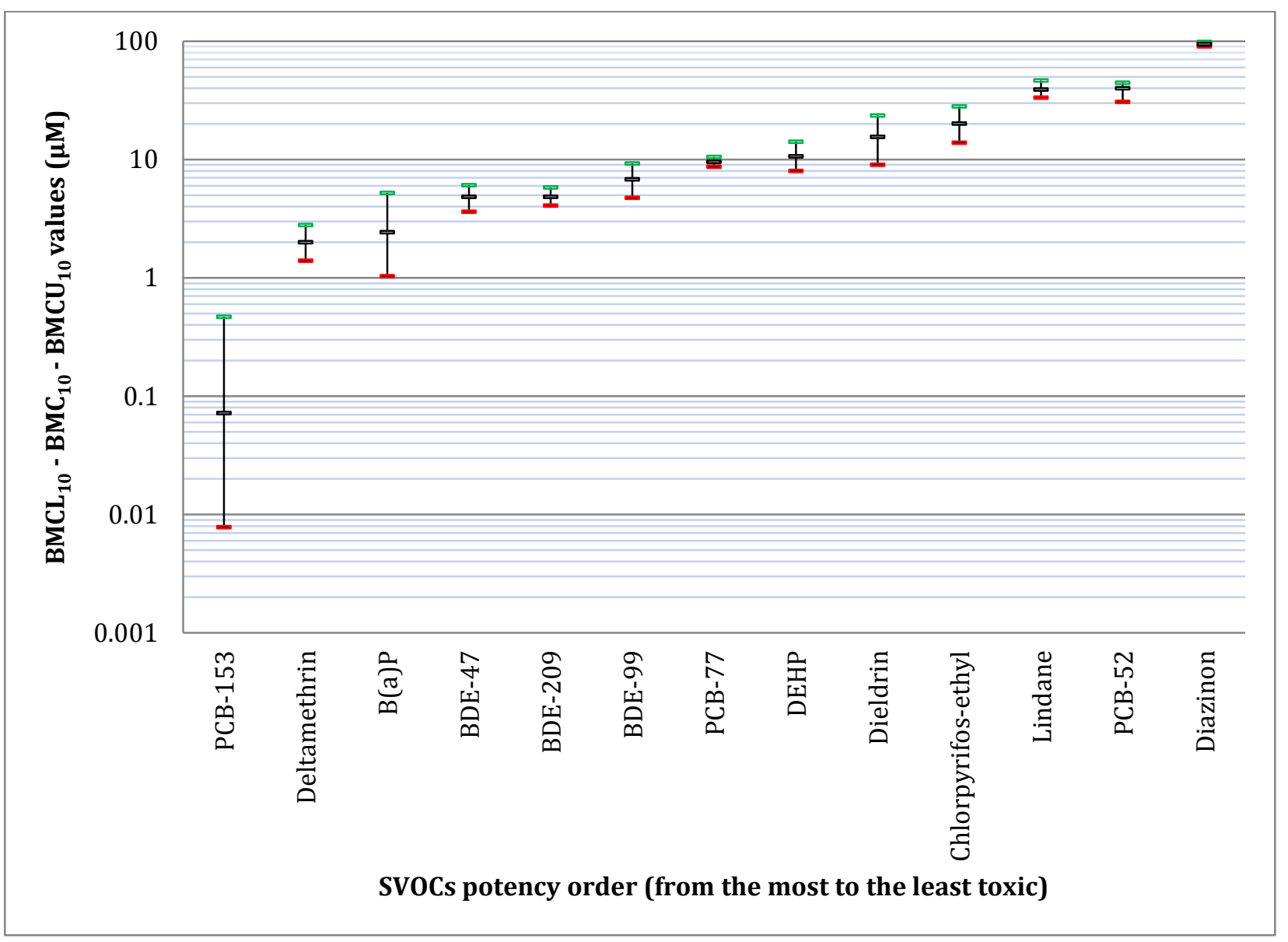


Table I - Indoor Semi Volatile Organic Compounds (SVOCs) candidates for grouping (detected in more than $10 \%$ of the French dwellings investigated).

\begin{tabular}{|l|l|}
\hline Chemical Family & Name \\
\hline Phthalates & DEHP, DEP, DBP, BBP, DiBP, DiNP, DMP \\
\hline $\begin{array}{l}\text { Polybromodiphenyl } \\
\text { ethers (PBDEs) }\end{array}$ & $\begin{array}{l}\text { BDE-28, BDE-47, BDE-85, BDE-99, BDE-100, BDE-153, BDE- } \\
\text { 154, BDE-209 }\end{array}$ \\
\hline $\begin{array}{l}\text { Polychlorobiphenyls } \\
\text { (PCBs) }\end{array}$ & $\begin{array}{l}\text { PCB-28, PCB-31, PCB-52, PCB-77, PCB-101, PCB-105, PCB-118, } \\
\text { PCB-138, PCB-153, PCB-180 }\end{array}$ \\
\hline $\begin{array}{l}\text { Polycyclic aromatic } \\
\text { hydrocarbons (HAPs) }\end{array}$ & $\begin{array}{l}\text { acenaphtene, anthracene, benzo(a)pyrene, fluorene, phenanthrene, } \\
\text { fluoranthene, } \\
\text { benzo(k)fluoranthene, benzo(b)fluoranthene, indeno(1,2,3-cd)pyrene, } \\
\text { benzo(g,h,i)perylene, dibenzo(a,h)anthracene }\end{array}$ \\
\hline Pesticides & $\begin{array}{l}\text { 4',4-DDE, 4',4-DDT, dieldrine, alpha-endosulfan, lindane, } \\
\text { chlorpyrifos-ethyl, diazinon, cyfluthrine, cypermethrine, } \\
\text { deltamethrine, permethrine, oxadiazon, tributylphosphate }\end{array}$ \\
\hline Others & $\begin{array}{l}\text { 4-tert-butylphenol, 4-tert-octylphenol, bisphenol A, galaxolide, } \\
\text { tonalide, triclosan } \quad ~\end{array}$ \\
\hline
\end{tabular}

Based on Mandin et al., 2014a; Mandin et al., 2014b; Blanchard et al., 2014 
Table II - Available data on in vitro neurotoxic effect for the 15 Semi Volatile Organic Compounds (SVOCs) retained for BMC calculations

\begin{tabular}{|c|c|c|c|c|c|c|}
\hline SVOC & Cell line & $\begin{array}{l}\text { Duration } \\
\text { of } \\
\text { exposure } \\
\text { (hours) }\end{array}$ & Test & $\begin{array}{l}\text { Tested } \\
\text { doses } \\
(\mu \mathrm{M})\end{array}$ & $\begin{array}{l}\text { Response: cell } \\
\text { viability } \\
\text { (standard } \\
\text { deviation) } \\
(\%) \\
\end{array}$ & Reference \\
\hline DEHP & Neuro-2a & 24 & MTT & $\begin{array}{l}0 \\
0.1 \\
1 \\
10 \\
40 \\
80\end{array}$ & $\begin{array}{l}100(0) \\
101.54(2.67) \\
103.08(8) \\
92.31(5.33) \\
56.15^{*}(21.3) \\
42.31 *(5.33)\end{array}$ & $\begin{array}{l}\text { (Lin et al. } \\
\text { 2011) }\end{array}$ \\
\hline BDE-47" & SK-N-MC & 24 & MTT & $\begin{array}{l}0 \\
1 \\
2.5 \\
5 \\
10 \\
15 \\
25 \\
50\end{array}$ & $\begin{array}{l}100(6.25) \\
95(3.75) \\
100(5) \\
78.75^{*}(5) \\
53.75^{*}(8.125) \\
35.25^{*}(7.5) \\
12.5^{*}(3.125) \\
5^{*}(1.25)\end{array}$ & $\begin{array}{l}\text { (Tagliaferri } \\
\text { et al. 2010) }\end{array}$ \\
\hline BDE-99\# & SK-N-MC & 24 & MTT & $\begin{array}{l}0 \\
1 \\
5 \\
10 \\
20 \\
30 \\
40 \\
50 \\
100 \\
\end{array}$ & $\begin{array}{l}100(9.375) \\
97.5(6.25) \\
95(8.75) \\
85^{*}(6.25) \\
72.5^{*}(10) \\
52.5^{*}(12.5) \\
45^{*}(7.5) \\
30 *(6.25) \\
17.5^{*}(4.375) \\
\end{array}$ & $\begin{array}{l}\text { (Tagliaferri } \\
\text { et al. 2010) }\end{array}$ \\
\hline BDE-209" & $\begin{array}{l}\text { Neonatal } \\
\text { hippocamp } \\
\text { al neurons } \\
\text { of SD rats } \\
\text { (PND1) }\end{array}$ & 24 & MTT & $\begin{array}{l}0 \\
10.43 \\
31.28 \\
52.13\end{array}$ & $\begin{array}{l}100(13.78) \\
81.03 *(11.72) \\
58.62 *(9.31) \\
45.17 *(3,45)\end{array}$ & $\begin{array}{l}\text { (Chen et al. } \\
\text { 2010) }\end{array}$ \\
\hline
\end{tabular}




\begin{tabular}{|c|c|c|c|c|c|c|}
\hline PCB-52 & SK-N-MC & 24 & $\begin{array}{l}\text { Trypan } \\
\text { Blue }\end{array}$ & $\begin{array}{l}0 \\
17.12 \\
34.25 \\
51.37 \\
68.49 \\
85.62\end{array}$ & $\begin{array}{l}100(0) \\
93.15(1.61) \\
68.55^{*}(3.63) \\
54.03 *(4.03) \\
18.15 *(2.02) \\
12.10 *(0.46)\end{array}$ & $\begin{array}{l}\text { (Lee et al. } \\
2005 \text { ) }\end{array}$ \\
\hline PCB $-77^{\#}$ & $\begin{array}{l}\text { Primary } \\
\text { cortical } \\
\text { cells of } \\
\text { Wistar rats } \\
\text { (GD 17-18) }\end{array}$ & 5 & MTT & $\begin{array}{l}0 \\
30 \\
50 \\
100\end{array}$ & $\begin{array}{l}100(5.61) \\
72.95 *(9.80) \\
60.38^{*}(8.87) \\
46.86^{*}(7.94)\end{array}$ & $\begin{array}{l}\text { (Sánchez- } \\
\text { Alonso et } \\
\text { al. 2003) }\end{array}$ \\
\hline PCB-118 & GT1-7 & 24 & $\begin{array}{l}\text { CellTiter } \\
\text {-Blue }\end{array}$ & $\begin{array}{l}0 \\
0.1 \\
1 \\
10 \\
100\end{array}$ & $\begin{array}{l}100(2,31) \\
67.47 *(1.03) \\
69.27 *(0.77) \\
69.88^{*}(0.26) \\
63.26 *(1.03)\end{array}$ & $\begin{array}{l}\text { (Dickerson } \\
\text { et al. 2009) }\end{array}$ \\
\hline PCB-153 & GT1-7 & 24 & $\begin{array}{l}\text { CellTiter } \\
\text {-Blue }\end{array}$ & $\begin{array}{l}0 \\
0.1 \\
1 \\
10 \\
100\end{array}$ & $\begin{array}{l}100(1.54) \\
74.84 *(1.03) \\
84.54 *(0.77) \\
61.20 *(0.51) \\
43.03 *(2.05)\end{array}$ & $\begin{array}{l}\text { (Dickerson } \\
\text { et al. 2009) }\end{array}$ \\
\hline $\mathbf{B}(\mathbf{a}) \mathbf{P}^{\mathcal{E}}$ & $\begin{array}{l}\text { Primary } \\
\text { cortical } \\
\text { cells of SD } \\
\text { rats (PND } \\
0-3)\end{array}$ & 40 & CCK-8 & $\begin{array}{l}0 \\
0.5 \\
1 \\
2 \\
5 \\
10 \\
20 \\
40 \\
80\end{array}$ & $\begin{array}{l}100(2.43) \\
94.77(4.05) \\
94.25(3.51) \\
90.29 *(2.70) \\
86.46 *(3.24) \\
80.48^{*}(2.70) \\
74.56 *(6.49) \\
67.37 *(5.41) \\
59.58^{*}(6.76)\end{array}$ & $\begin{array}{l}\text { (Nie et al. } \\
2014 \text { ) }\end{array}$ \\
\hline $\mathbf{B P A}^{\#}$ & HT-22 & 24 & MTT & $\begin{array}{l}0 \\
1 \\
10 \\
50 \\
100 \\
500\end{array}$ & $\begin{array}{l}100(12.59) \\
154.55(48.81) \\
210(124.40) \\
308.18 *(70.86) \\
217.27 *(29.91) \\
27.27 *(15.74)\end{array}$ & $\begin{array}{l}\text { (Lee et al. } \\
2008)\end{array}$ \\
\hline
\end{tabular}




\begin{tabular}{|c|c|c|c|c|c|c|}
\hline Dieldrin $^{\#}$ & N27 & 48 & MTT & $\begin{array}{l}0 \\
10 \\
25 \\
50 \\
75 \\
100\end{array}$ & $\begin{array}{l}100(5.33) \\
82.75(5.77) \\
65.26 *(9.77) \\
37.30 *(8.00) \\
23.55^{*}(7.10) \\
12.12 *(10.22)\end{array}$ & $\begin{array}{l}\text { (Sharma et } \\
\text { al. 2010) }\end{array}$ \\
\hline Lindane $^{\#}$ & $\mathrm{~N} 27$ & 48 & MTT & $\begin{array}{l}0 \\
10 \\
25 \\
50 \\
75 \\
100\end{array}$ & $\begin{array}{l}100(1.33) \\
99.49(2.67) \\
92.05(4.00) \\
87.95(7.10) \\
81.03 *(3.55) \\
79.49 *(8.44)\end{array}$ & $\begin{array}{l}\text { (Sharma et } \\
\text { al. 2010) }\end{array}$ \\
\hline Diazinon $^{\#}$ & PC12 & 48 & MTS & $\begin{array}{l}0 \\
100 \\
200 \\
300 \\
400\end{array}$ & $\begin{array}{l}100(1.84) \\
91.32 *(2.77) \\
79.62 *(2.77) \\
75.47 *(0.47) \\
67.92 *(0.93)\end{array}$ & $\begin{array}{l}\text { (Bahrami } \\
\text { et al. 2013) }\end{array}$ \\
\hline $\begin{array}{l}\text { Chlorpyrifos- } \\
\text { ethyl }^{\#}\end{array}$ & SH-SY5Y & 24 & MTS & $\begin{array}{l}0 \\
25 \\
50 \\
100 \\
200\end{array}$ & $\begin{array}{l}100(0) \\
91.25 *(7.27) \\
72.50 *(10.62) \\
54.50 *(10.62) \\
32.75 *(10.06)\end{array}$ & $\begin{array}{l}(\mathrm{Ki} \text { et al. } \\
2013)\end{array}$ \\
\hline $\begin{array}{l}\text { Deltamethrine } \\
\#\end{array}$ & SH-SY5Y & 24 & MTT & $\begin{array}{l}0 \\
0.01 \\
0.1 \\
1 \\
10 \\
100 \\
1000\end{array}$ & $\begin{array}{l}100(9.26) \\
105.10(1.99) \\
99.38(7.94) \\
93.13(11.25) \\
76.57 *(9.93) \\
62.19 *(7.27) \\
43.13 *(5.95)\end{array}$ & $\begin{array}{l}\text { (Romero et } \\
\text { al. 2012a) }\end{array}$ \\
\hline
\end{tabular}

* Results differ significantly from the control

\# Data was obtained by manual measures conducted on the graphics directly

${ }^{\&}$ Treated with $S 9$ in order to metabolize the parent compound

MTT: Mitochondrial functionality test based on formazan product formation insoluble in water; MTS: Mitochondrial functionality test based on formazan product formation soluble in water; CCK-8: Commercial kit of the MTS test; CellTiter-Blue: Commercial kit of the resazurin test; Trypan Blue: Membrane integrity test; SD: Sprague Dawley; GD: Gestational day; PND: Postnatal day; GT1-7: Hypothalamic cells of mice; HT-22: Hippocampal cells of mice; N27:Dopaminergic cells of rats; Neuro-2a: Neuroblastoma cells of mice; PC12: Pheochromocytoma cells of rats; SH-SY5Y: Human neuroblastoma cells; SK-N-MC: Human neuroblastoma cell 
Table III - BMC10 of the 13 Semi Volatile Organic Compounds (SVOCs) ultimately selected, on the basis of in vitro neuronal death

\begin{tabular}{|l|l|l|l|l|l|}
\hline SVOC & $\begin{array}{l}\text { Number of Hill } \\
\text { parameters }\end{array}$ & $\begin{array}{l}\text { Log } \\
\text { likelihood }\end{array}$ & $\begin{array}{l}\mathrm{BMC}_{10} \\
(\mu \mathrm{M})\end{array}$ & $\begin{array}{l}\mathrm{BMCL}_{10} \\
(\mu \mathrm{M})^{*}\end{array}$ & $\begin{array}{l}\mathrm{BMCU}_{10} \\
(\mu \mathrm{M})^{*}\end{array}$ \\
\hline PCB-153 & 3 & 21.82 & 0.072 & 0.00781 & 0.46987 \\
\hline Deltamethrin & 3 & 50.12 & 1.996 & 1.3991 & 2.7856 \\
\hline B(a)P & 4 & 66.52 & 2.43 & 1.0346 & 5.2125 \\
\hline BDE-47 & 4 & 41.4 & 4.83 & 3.6287 & 6.0664 \\
\hline BDE-209 & 2 & 21.4 & 4.84 & 4.0828 & 5.812 \\
\hline BDE-99 & 3 & 16.46 & 6.80 & 4.7495 & 9.2436 \\
\hline PCB-77 & 2 & 35.77 & 9.54 & 8.6715 & 10.533 \\
\hline DEHP & 4 & 32.13 & 10.64 & 8.0276 & 14.096 \\
\hline Dieldrin & 3 & 4.11 & 15.54 & 9.032 & 23.585 \\
\hline Chlorpyrifos & 3 & 18.97 & 20.09 & 13.848 & 28.168 \\
\hline Lindane & 2 & 38.9 & 38.93 & 33.302 & 46.513 \\
\hline PCB-52 & 4 & 12.71 & 39.89 & 30.724 & 44.39 \\
\hline Diazinon & 2 & 80.21 & 94.35 & 90.24 & 98.788 \\
\hline
\end{tabular}

* BMCL and BMCU are respectively the lower and upper $90 \%$-confidence bounds. 